\title{
Giant gluteal pilomatrixoma: An uncommon tumor in a rare localization
}

\author{
Dev gluteal pilomatriksoma: Nadir bir lokalizasyonda sıradıșı bir tümör
}

Murat Özgür KILIÇ, Meral ŞEN

\begin{abstract}
Pilomatrixoma is an uncommon, benign subcutaneous tumor arising from the hair follicle matrix. This tumor occurs more commonly in children than in adults, and most often originates on the head, neck or upper extremities. Gluteal region is an extremely rare site of pilomatrixoma. Multiple presentation is an unusual condition and often associated with some familial syndromes such as myotonic dystrophy, Gardner syndrome and Turner syndrome. Pilomatrixoma mostly presents as a painless, firm, slow-growing subcutaneous mass, and is usually encapsulated by connective tissue and sharply demarcated from the surrounding normal tissue. Both clinical and radiological findings are non-specific, and therefore histopathology is necessary to reach correct diagnosis. These lesions have very low risk of malignant transformation, and surgical excision with adequate margins is the treatment of choice. Herein, a rare case of gluteal pilomatrixoma with multiple presentation in the upper extremities in a young female patient was presented.
\end{abstract}

Keywords: Diagnosis, Gluteus, Pilomatrixoma, Treatment

\section{ÖZET}

Pilomatriksoma saç folikülü matriksinden kaynaklanan nadir, benign bir cilt altı tümörüdür. Bu tümör yetişkinlere oranla çocuklarda daha sık görülür ve çoğu baş, boyun veya üst ekstremitelerden köken alır. Gluteal bölge, pilomatriksomanın çok nadir görülen bir bölgesidir. Multipl prezentasyon sık olmayan bir durumdur ve genellikle miyotonik distrofi, Gardner sendromu ve Turner sendromu gibi bazı ailesel sendromlar ile ilişkilidir. Pilomatriksoma çoğunlukla ağrısız, sert, yavaş büyüyen bir cilt altı kitlesi olarak ortaya çıkar ve genellikle bağ dokusu ile kapsüllü

Murat Özgür Kılıç (凶), Meral Şen

Department of General Surgery, School of Medicine, Turgut Özal University, Ankara, Turkey

e-mail:murat05ozgur@hotmail.com

Submitted/Gönderme: 01.06 .2015

Accepted/Kabul: 02.09.2015 ve normal çevre dokudan keskin olarak sınırlanmıştır. Hem klinik ve hem de radyolojik bulgular spesifik değildir ve bu nedenle histopatoloji doğru tanıya ulaşmak için gereklidir. Bu lezyonlar çok düşük malign transformasyon riskine sahiptir ve tedavisi yeterli sınırlar ile cerrahi eksizyondur. Bu yazıda, genç bir kadın hastada, üst ekstremite multipl prezentasyon ile birlikte olan nadir bir gluteal pilomatriksoma olgusu sunuldu.

Anahtar kelimeler: Diagnosis, Gluteus, Pilomatriksoma, Tedavi

\section{Introduction}

Pilomatrixoma or pilomatricoma (PM) is a benign cutaneous tumor originating from the hair matrix, and is mostly common in the first two decades of life [1]. The most affected anatomical sites are head, neck, and upper extremities [1]. However, PM are rarely found in the other parts of the body, especially in the gluteal region. The main presenting symptom is a solitary, subcutaneous, slowly growing nodular mass usually measuring less than $15 \mathrm{~mm}$ in diameter [2]. Large tumors and multiple presentations are unusual conditions, and may be associated with some familial syndromes [3]. Surgical excision with wide margins is the treatment of choice due to the risk of recurrence [4]. Herein, we report a giant PM in a 33-year-old female presenting with an irregular gluteal mass clinically thought to be malignant.

\section{Case Report}

A 33-year-old female patient presented at our institute with a slow growing and painful right gluteal mass. The physical examination revealed a solid, subcutaneous tumoral lesion of about $7 \times 5 \mathrm{~cm}$ in size in the right gluteal region. The skin over the mass was erythematous (Figure 1). In addition, multiple similar lesions, the largest of $1 \mathrm{~cm}$ in size, were found out 
in the upper extremities. No regional lymphadenopathy was detected clinically. The patient did not have any other skin disease or familial history of any systemic syndrome. Ultrasound (US) examination revealed a subcutaneous heterogeneus lesion of about $8 \times 5 \mathrm{~cm}$ in size, with cycstic areas and calcifications in the centre of the mass. Magnetic resonance imaging (MRI) showed a subcutaneous, lobulated, malignant-suspected lesion in the right gluteal region, which was hypointense in $\mathrm{T} 1$ and $\mathrm{T} 2 \mathrm{~A}$ sequences with minimally peripheral edema (Figure 2). A tru-cut biopsy was performed due to the clinical and radiological suspicion of malignancy, and the gluteal mass was diagnosed as a benign PM. In addition, the diagnosis of the similar lesions on the arms was also confirmed histopathologically. The tumor was completely excised under spinal anaesthesia (Figure 3). On histopathological examination, a nodular lesion, $7 \times 6 \times 3 \mathrm{~cm}$ in size and composed of solid nests of basoloid cells with squamous ghost cells, was defined as PM (Figure 4). The patient was discharged on third day without any problem, and no recurrence was observed during the follow-up period of approximately one year. Permission was obtained from the patient for publicaiton of her photographs.

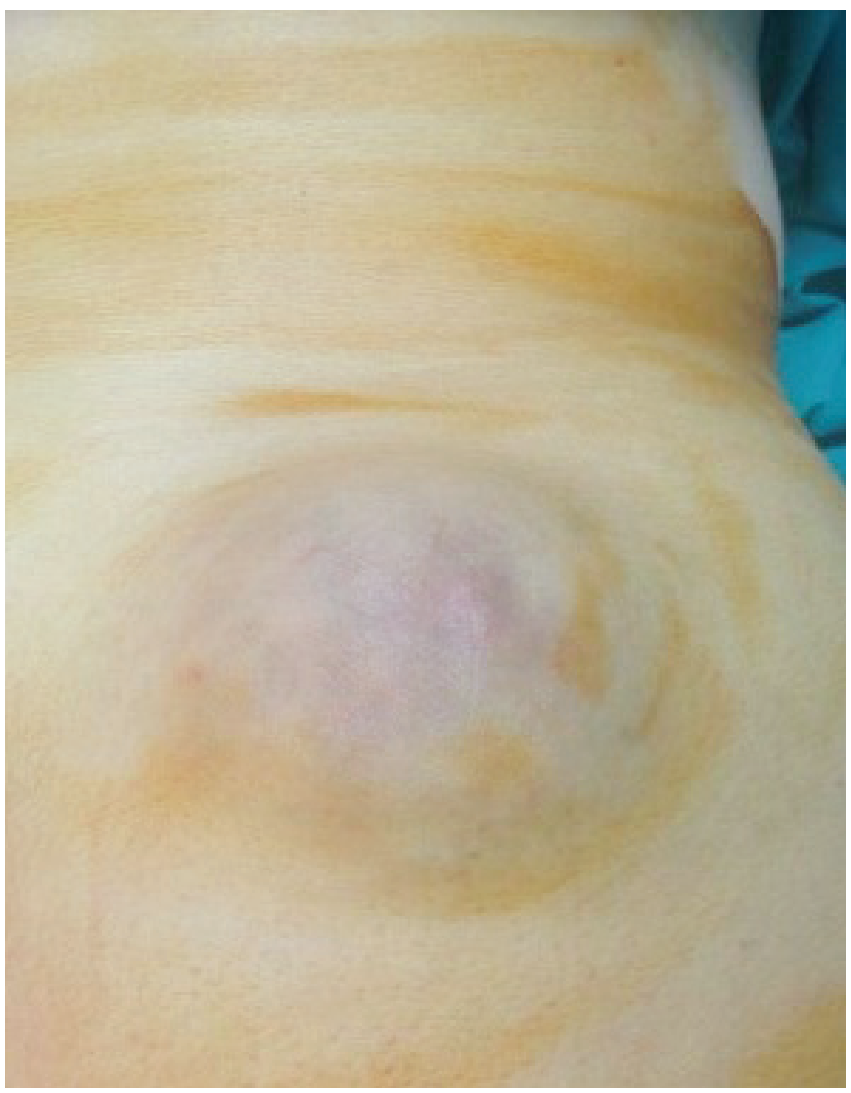

Figure 1. Tumoral lesion in the right gluteal region. Erythematous skin is seen over the tumor.

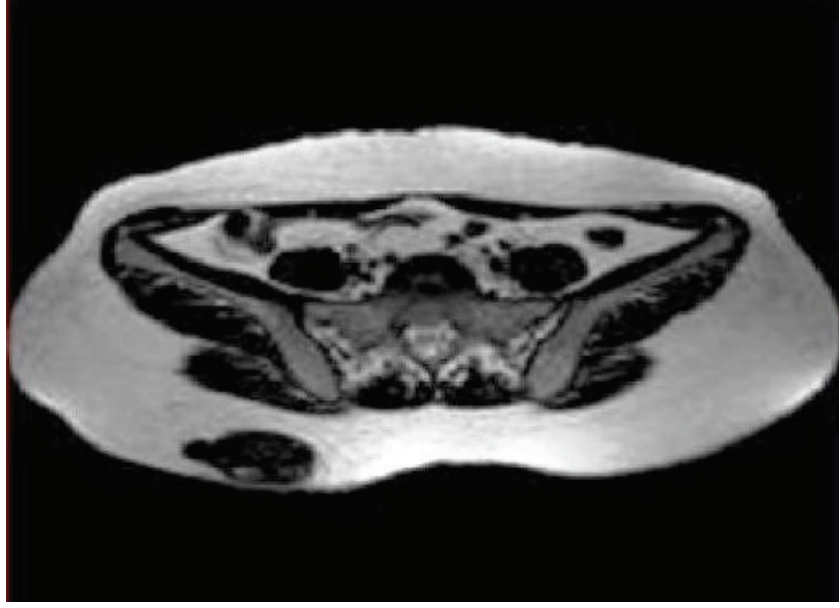

Figure 2. Subcutaneous hypointensive mass located in the right gluteal region (axial T2).

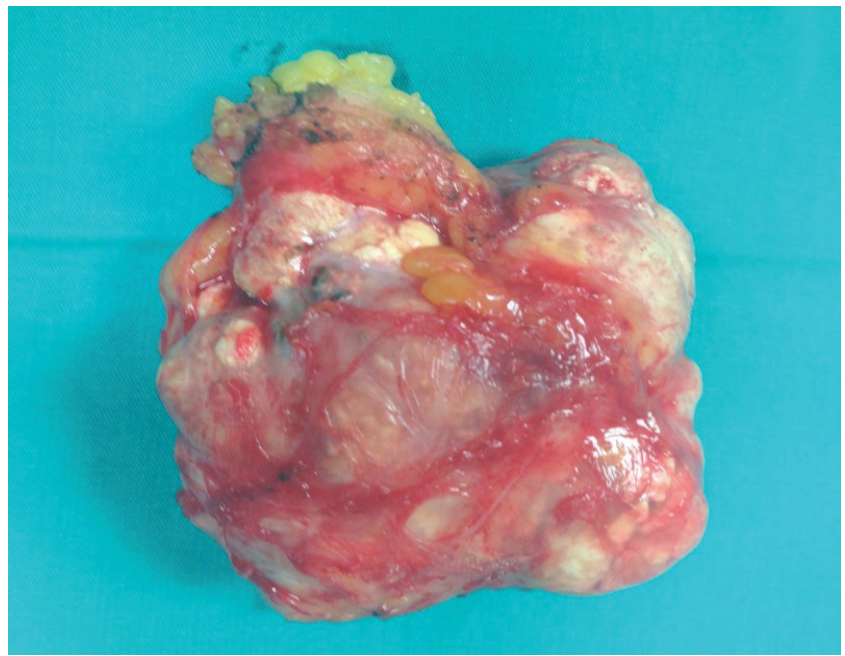

Figure 3. Totally excised PM

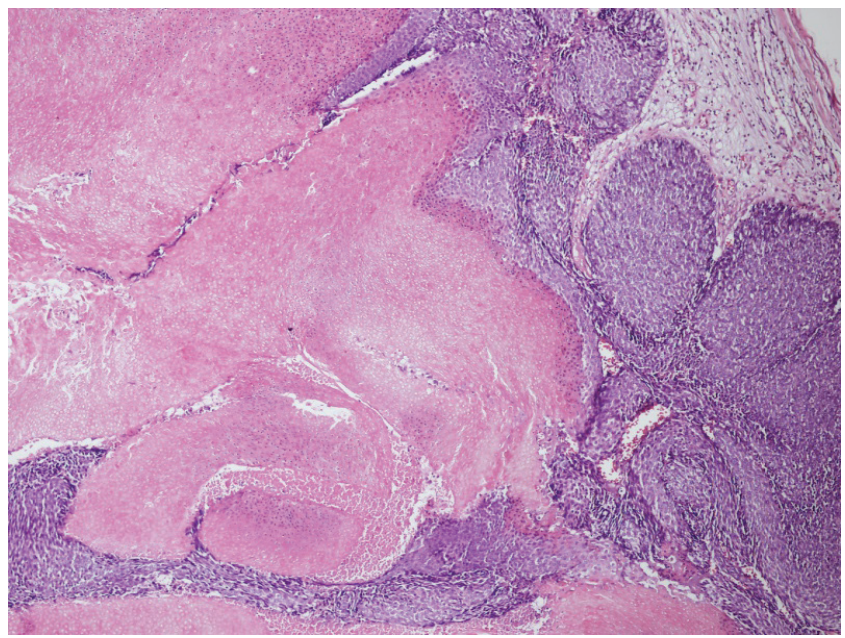

Figure 4. Epitel islands with centrally settled ghost cells and periferrally surronded by proliferated basal cells. There is no atypia, necrosis and infiltrative border (H\&E X100). 


\section{Discussion}

Pilomatrixoma, also known as calcifying epithelioma of Malherbe, was first described by Malherbe as a neoplasm of the sebaceous gland. Later on, the term was changed to "pilomatrixoma" by Forbis and Helwig according to its origin of the hair matrix. The neck and cheek are the most common sites in children, while the scalp and neck are the most common sites in adults. However, gluteal region is very rare. PM typically presents as a superficial, firm, solitary and painless mass of the dermis. These tumors constitute approximately $1 \%$ of all benign skin lesions, and usually grows slowly over a period of several months or years [2]. Similarly, our patient presented with a slow growing and mild-tender right gluteal mass. Although, PM can be seen at any age, it often occurs before the age of 20 years with a slight female predilection [1]. However, a second, smaller peak of onset has been reported in the elderly [3]. The lesions are usually less than $15 \mathrm{~mm}$, and sometimes in association with slight bluish/reddish coloration of the skin $[2,5,6]$. In the present case, the lesion was irregular and $7 \times 5 \mathrm{~cm}$ in diameter with superficial hyperemia, clinically thought to be malignant. The lesions larger than $5 \mathrm{~cm}$ are generally defined as giant PMs [7]. To our knowledge, the largest reported PM in the literature was $24 \mathrm{~cm}$ in size and located in the upper back [8]. Multiple presentation of PM is an unusual condition, and is generally associated with various systemic syndromes, of which myotonic dystrophy has been the most described [1,9]. Our patient had a giant PM in the gluteal region with multiple similar and smaller lesions on the skin of upper extremities. She had no familial or systemic syndrome related to PM. Her familial history was also negative for PM.

The clinical diagnosis of PM is often difficult, particularly for the lesions in unusual localizations. PM unfortunately has non-specific radiological findings; however complementary imaging methods including US, computed tomography (CT) and MRI are needed to establish a differential diagnosis with other benign and malign lesions such as sebaceous cyst, giant dermatofibroma, neurofibromas, nodular basal cell carcinoma and foreign body reaction $[2,8]$. US, as a rapid, non-invasive and inexpensive test, is often the first step radiological test in diagnostic algoritm. The others, CT scan and MRI, may give more information about the nature and margins of the lesion as well as its relationship with adjacent structures, and thus may be more helpful in surgical planning. However, it was reported that typical imaging findings should not be expected in cases of giant PMs [10]. Both US and MRI were used in the preoperative evaluation of our patient. On the other hand, the diagnosis of PM should be always confirmed histopathologically. In this regard, fine-needle aspiration biopsy or tru-cut biopsy should be performed before surgical intervention for distinguishing other similar pathologies and low risk of malignancy. Indeed, malign transformation of PM is extremely rare, and usually occurs in middle-aged or elderly patients. Malign PMs are also associated with high rates of local invasion as well as metastasis [11]. Histopathologic examination of PM generally shows solid nests of basaloid cells with the formation of ghost cells; however, calcification and ossification can be observed in some cases.

The spontaneous regression of PM has never been reported [1]. For this reason, simple surgical excision of the lesion should be the treatment of choice. Surgery is associated with a very low relapse rate probably due to incomplete excision [2]. Similarly, in the present case, no recurrence has been observed within the follow-up period of one year.

Finally, PM is well recognised by dermatologists and pathologists, but it is an unusal lesion for other clinicans such as general surgeons. Moreover, gluteal region is an extremely rare site of PM. Due to non-specific clinical and radiological features, histopathology is the most definitive means of diagnosis. Simple surgical removal of the lesion with adequate margins is considered to be the treatment of choice, with a very low relapse rate.

\section{References}

1. Kovacic M, Rudic M, Nekic I, Lisica-Sikic N, Kranjcec Z, Simurina T. Giant pilomatrixoma (benign calcifying epithelioma of Malherbe) of the neck and face. Dermatol Surg 2007;33:340-3. doi: 10.1111/j.1524-4725.2007.33070.x

2. Guinot-Moya R, Valmaseda-Castellon E, Berini-Aytes L, GayEscoda C. Pilomatrixoma. Review of 205 cases. Med Oral Patol Cir Bucal 2011;16:e552-5. doi: 10.4317/medoral.16.e552

3. Maeda D, Kubo T, Miwa H, et al. Multiple pilomatricomas in a patient with Turner syndrome. J Dermatol 2014;41:563-4. doi: 10.1111/1346-8138.12509

4. Roche NA, Monstrey SJ, Matton GE. Pilomatricoma in children: Common but often misdiagnosed. Acta Chir Belg 2010;110:250-4.

5. Sable D, Snow SN. Pilomatrix carcinoma of the back treated by mohs micrograph surgery. Dermatol Surg 2004;30:1174-6. doi: 10.1111/j.1524-4725.2004.30350.x

6. Whittemore KR, Cohen M. Imaging and review of a large pre-auricular pilomatrixoma in a child. World J Radiol 2012;4:228-30. doi: 10.4329/wjr.v4.i5.228

7. Lozzi GP, Soyer HP, Fruehauf J, Massone C, Kerl H, Peris K. Giant pilomatricoma. Am J Dermatopathol 2007;29:286-9. doi: 10.1097/DAD.0b013e318053db45

8. Gongidi P, Meshekow J, Holdbrook T, Germaine P. Giant pilomatrixoma presenting in the posterior thorax, a 
rare location and the largest described. Case Rep Radiol. 2015;2015:590742. (doi: 10.1155/2015/590742)

9. Geh JL, Moss AL. Multiple pilomatrixomata and myotonic dystrophy: a familial association.Br J Plast Surg 1999;52:1435. doi: 10.1054/bjps.1998.3036

10. Ribeiro BN, Marchiori E. Giant pilomatrixoma: conventional and diffusion-weighted magnetic resonance imaging findings. Radiol Bras 2015;48:63-4. doi: 10.1590/01003984.2014.0071

11. Herrmann JL, Allan A, Trapp KM, Morgan MB. Pilomatrix carcinoma: 13 new cases and review of the literature with emphasis on predictors of metastasis. J Am Acad Dermatol 2004;71:38-43.e2. doi: 10.1016/j.jaad.2014.02.042 